\title{
1: 200897271-200891127
}

National Cancer Institute

\section{Source}

National Cancer Institute. 1:200897271-200891127. NCI Thesaurus. Code C44974.

Physical location of KISS1_Gene 